\title{
Estimation of hydrodynamic pattern change of Ichamati River using HEC RAS model, West Bengal, India
}

\author{
Ismail Mondal $^{1} \cdot$ Jatisankar Bandyopadhyay $^{1} \cdot$ Ashis Kr. Paul $^{2}$
}

Received: 27 April 2016/Accepted: 21 May 2016/Published online: 4 July 2016

(C) Springer International Publishing Switzerland 2016

\begin{abstract}
The physically-based hydrodynamic model can simulate the water flow dynamics of a stream network against time varying boundary conditions that can be implemented for the case of Ichamati River. Such river models are often an important component of flood forecasting, tidal fluctuation system that forecasts river levels in flood prone regions of the middle stream of Ichamati river. The measurements of river bed depth/slope, water quality (river cross section), floodplain mapping and boundary condition flow are essential for the set up of a river model. But one can use proxy approaches relying mostly on remote sensing data from space platforms for the purpose. In this study, we set up the one dimensional river analysis system (RAS) model of the hydrologic engineering center (HEC) over the stream network of the Ichamati river basins. Good quality in situ measurements of river hydraulics (cross section, slope, flow) were available only for the upstream and middle stream flood prone region of the basin. The de-siltation of the stretch of Ichamati river under survey i.e. middle part showed impacts which were positive in ways more than one. The river velocity in the top strata is $0.3 \mathrm{~m} / \mathrm{s}$ from model and the river regained its ecological flow. Also, the increased salinity of the river helped in cultivation of different species of fishes, which are socio economically relevant in the adjoining areas. Due to the increased capacity of the channel in the middle part possibility of flood has also decreased. The total volume of
\end{abstract}

Ismail Mondal

ismailmondal58@gmail.com

1 Department of Remote Sensing and GIS, Vidyasagar University, Paschim, Medinipur 721102, India

2 Department of Geography and Environment Management, Vidyasagar University, Paschim, Medinipur 721102, India silt accumulated has been estimated $277,589.92 \mathrm{~m}^{3}$. The rate of sedimentation was then calculated and found to be $16,328.82 \mathrm{~m}^{3} /$ month silt deposition during monsoon and $11,109 \mathrm{~m}^{3}$ silt deposition during non monsoon period. It may be concluded that out of $6 \%$ annual silt deposition, $5 \%$ silt deposition took place during the month between June and October and $1 \%$ silt deposition during the month between November and May. Silt excavation along $20 \mathrm{~km}$ stretch of Ichamati river showed distinct rejuvenation of the river stretch. The program of silt excavation along other stretches of river Ichamati study area would certainly bring positive impact on the river ecology and environment. Ecological flow needs to be maintained in rivers in the upstream due to chocking the silt deposition. Ecological flow in Ichamati river is absent in many stretches of the river due to heavy silt deposition.

Keywords Hydrodynamic modeling $\cdot$ HEC-RAS $\cdot$ Remote sensing $\cdot$ Hydraulic simulation $\cdot$ Nonlinear unsteady flow

\section{Introduction}

In the eastern side of the Bhagirathi/Hooghly River the only major river is the Ichamati river which is a link between the 'Nadia group of rivers' (viz. Jalangi, Mathabhanga, Churni etc.) in the north and Sundarban in the south (Chakravarti 1938; Mondal and Bandyopadhyay 2014b). The Ichamati river, a spill channel of Mathabhanaga river, originating from Majdia (krishnaganj Block) Nadia district, India and Bangladesh (for a short distance) enters into the 24 Parganas (north) district at Bagdah block subsequently, the Ichamati river flowing through eastern part of the 24 Parganas (north and south) districts ultimately debouches in the Raimangal river vis-a-vis the bay 
of Bengal. The Ichamati river could be subdivided into two segments on the basis of the river morphology.

\section{Upper stretch}

Brand off point from Mathabhanaga river at Majdia, Krishnaganj Block, Nadia District and beri/Swarupnagar, 24 Parganas $(\mathrm{N})$ district. In this stretch the river is moribund in nature with high sinuosity and serpentine meanders exhibiting numerous abandoned scrolls/oxbow lakes. In this part, the river is practically not receiving any upland flow excepting in rainy season. (Mondal and Bandyopadhyay 2014a, b, c; Mondal and Satpati 2012).

\section{Lower segment}

From Beri/Swarupnagar to Bay of Bengal. In this portion, the channel width gradually increases as semidiurnal tidal flow exists. In this stretch, Jamuna river is a tributary to the Ichamati river and joins at Tipi, 24Parganas (N). The lower most part of the river is funnel shaped (Chakravarti 1938; Mondal and Bandyopadhyay 2014a, b, c).

River banks areas are the upper parts in any of its crosssection and it may or may not consist of manmade structures to have influences on the natural morphodynamic system of the channel. After the bed, bank is the second most important component of the river channel and it is a transverse vector of the channel. The river banks gradually descend up to the river bed and the cross-profile may consist of different slop elements. The nature of put significant influences on the morphological equilibrium of the channel in relation its ambient environmental set up. The bank area of a deltaic river channel is highly influence by tidal conditions. When the river is in low tidal level, the bank of river channel is further exposed (Mondal and Satpati 2012) but a high tide situation, when the river is full to its brim, much of its bank area is inundated. The present study attempted to study the morphodynamics setting and erosion status of the river banks of the Ichamati, a decaying river located in the eastern part of Ganga delta region of West Bengal (Chakravarti 1938; Mondal and Bandyopadhyay 2014a, b, c; Mondal and Satpati 2012).

\section{Background of study area}

In the study area of Bangaon subdivision District of North 24 Parganas, West Bengal of Trans International IndoBangladesh border, this area is very highly restricted Border Security zone of Bagdah, Bangaon, Swarupnagar and Gaighata Block. This area is located $23^{\circ} 04^{\prime} \mathrm{N}-$ $23^{\circ} 07^{\prime} \mathrm{N}$ and $88^{\circ} 07^{\prime} \mathrm{N}$ and $88^{\circ} 49^{\prime} \mathrm{E}$ to $88^{\circ} 82^{\prime} \mathrm{E}$ (Fig. 1). These blocks are situated on the northern part of North 24
Parganas District in West Bengal, its eastern side has international border with Indo-Bangladesh, Nadia District situated on west, and northern side has Bagdah block and also southern side bounded by Gaighata block. The study areas covered maximum portion of the Ichamati river channel. So this area are connected India and Bangladesh by NH 35 and road is called Jassore Road which built up by King Saharsa and Eastern Railway connected by Sealdah to Bangaon.

\section{Aim}

To identify the Morphodynamic change of Ichamati River by HEC RAS Model.

\section{Object of the study}

To find out the required detailed field surveys covering the topological, Geological, geotechnical, geophysical and hydro geological aspects, agriculture soil survey etc. To assess easement of drainage congestion which occur at regular intervals during heavy down course, particularly in the blocks of Bagdah, Bangaon and Gaighata.

River bed shifting of the study area.

Land acquisition proposals vis-à-vis the possibilities of reduction or avoidance in view of likely impact on agriculture land, wetland, etc., in the study area.

To record field data in a systematic, meaningful way. Gain knowledge about shear stresses that causes failures on hydraulic structures.

Able to calculate some parameters with available data for Natural Rivers.

To establish the hydraulic geometry of Ichamati river by HEC RAS Model.

To study the changes of channel capacity width, depth, meander, of rating curve by HEC RAS Model etc.

\section{Topography and physiography}

Bhagirathi-Hooghly river is the western most major distributry channel of the Ganga delta. In the east other distributaries are Bhairab, Sialmari, Jalangi, MathabhangaChurni-Ichamati rivers (commonly known as "Nadia Group of Rivers") up to Bangladesh border. In general, the Bhagirathi-Hooghly river is taken as the western limit of the Ganga delta. However, studies on palaeogeographic development of the Ganga delta (Niyogi 1975; Umitsu 1993; Acharya et al. 1999) indicate that the BhagirathiHooghly river has shifted towards east through space and 
Fig. 1 Location map

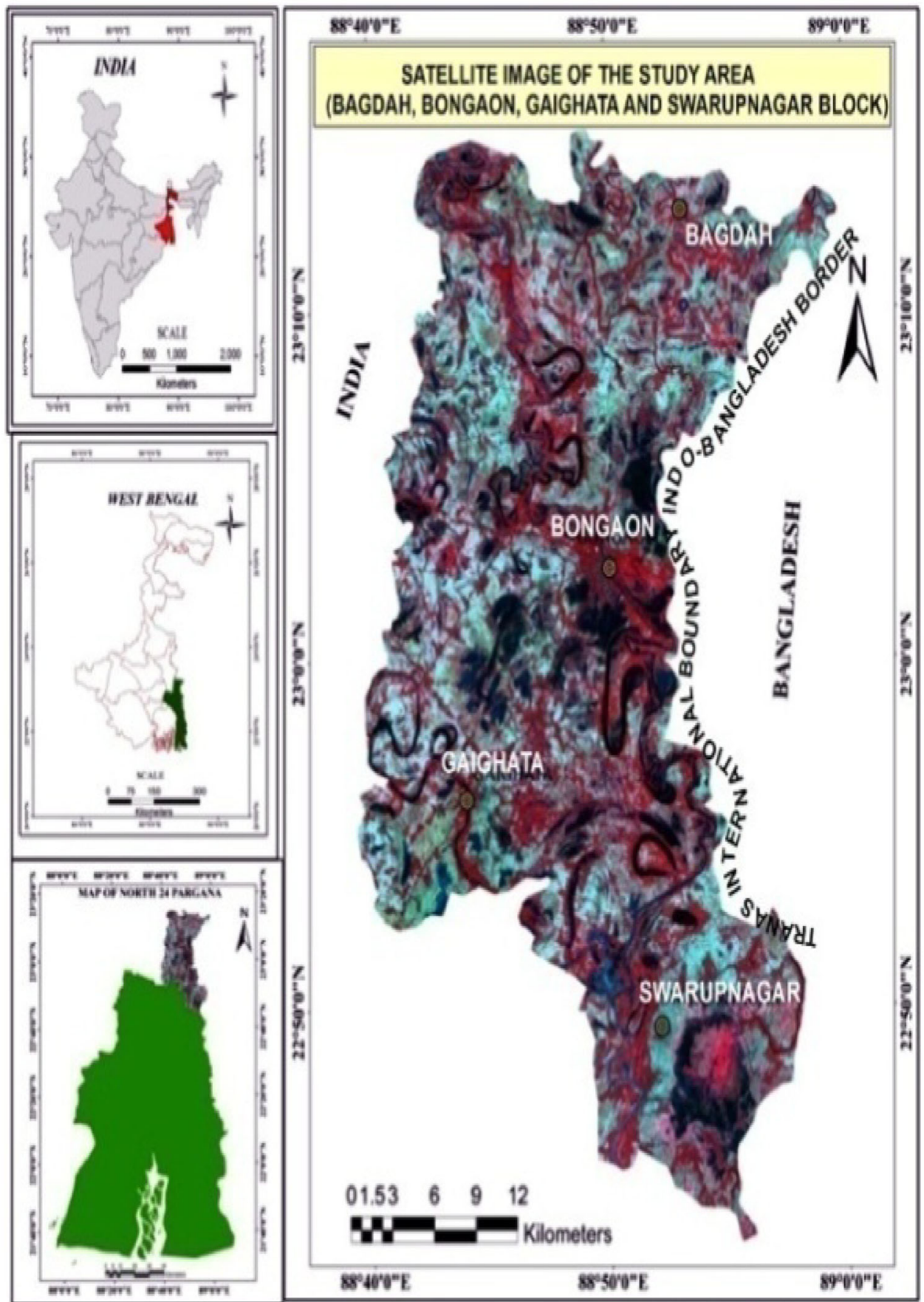

time with the development of the deltas of the peninsular rivers (viz. Mayurakshi, Ajay, Damodar) coupled with neotectonic activities. Thus a narrow strip of low laying land (Younger Alluvial Plain) developed in the western side of the Bhagirathi-Hooghly river bording older Alluvial Plain. The N-S alignment of the low marshy lands (with reasonal water bodies/wet lands, meander scars, cutoff meanders), 'bils/jhils' in the western part of the present Bhagirathi river in the Alluvial upland are in the same alignment of the present $\mathrm{N}-\mathrm{S}$ straight course of the Damodar river (further downstream of the Bhagirathi river) which may be considered as a mega lineament and with all probability, this was the ancient course of the Ganga river any time before 800 A.D. Roy 1952) (Fig. 2).

Serpentine (scroll) meandering zone of the Bhagirathi river between-Samudragarh-Dhatrigram stretch, Burdwan (Barddhaman) district and adjacent part of Nadia district may be: 
Fig. 2 Geomorphology map

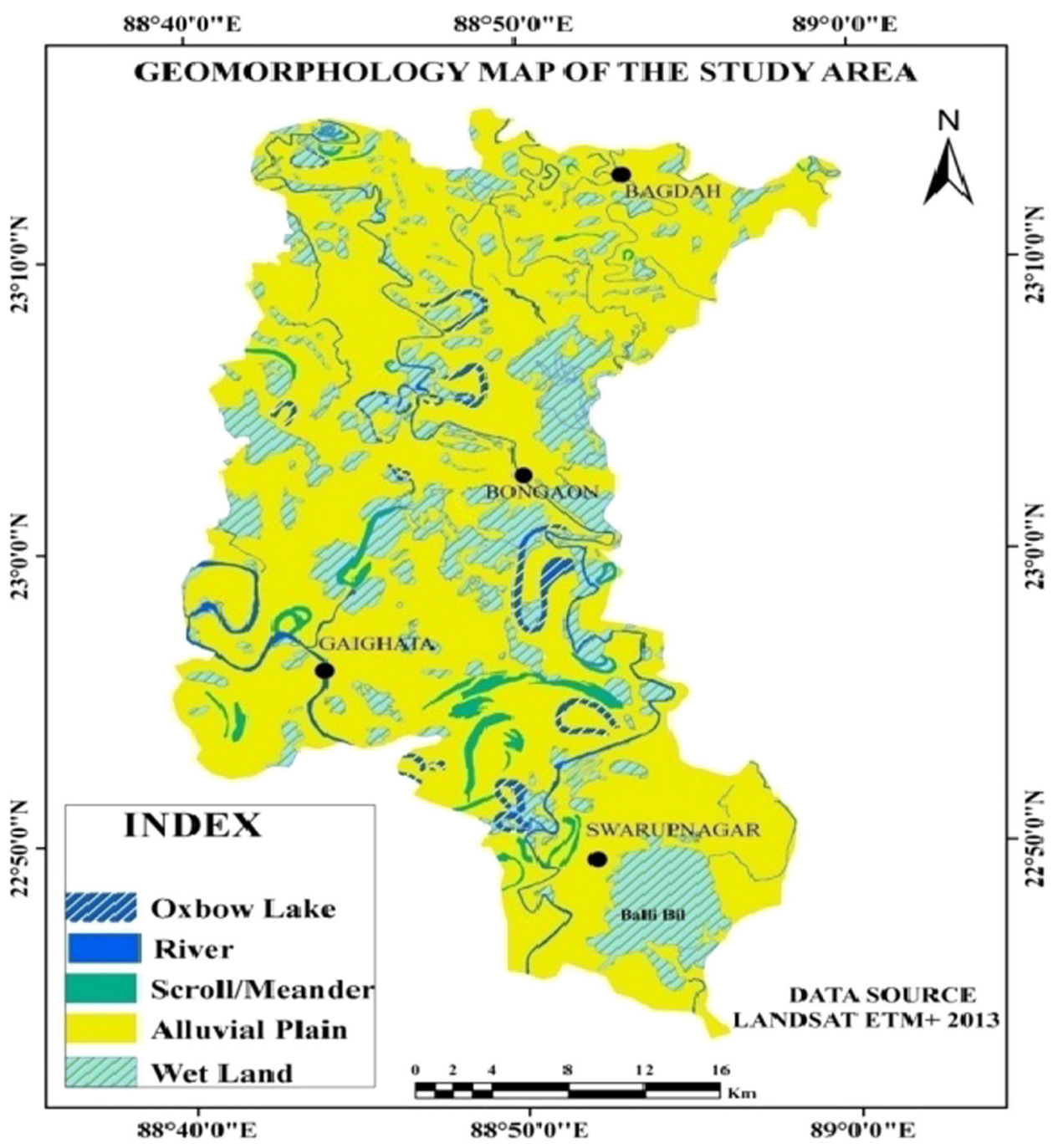

1. Reflection in the change in riverine discharge and tidal flow of Hooghly river.

2. Surface expression of normal fault running through the Burdwan-Debgram-Jalangi area (cf. Sengupta 1966, refer Chapter II).

\section{River and drainage pattern}

In the eastern side of the Bhagirathi/Hooghly River the only major river is the Ichamati river which is a link between the 'Nadia group of rivers' (viz. Jalangi, Mathabhanga, Churni etc.) in the north and Sundarban in the south. The Ichamati river, a spill channel of Mathabhanaga river,originating from Majdia (krishnaganj block) Nadia District, India and Bangladesh (for a short distance) enters into the 24 Parganas (north) district at Baghda block subsequently, the Ichamati river flowing through eastern part of the 24 Parganas (north and south) districts ultimately debouches in the Raimangal river vis-a-vis the bay of Bengal. The Ichamati river could be subdivided into two segments on the basis of the river morphology (Fig. 3).

\section{What is a hydrodynamic model}

Hydrodynamics is the study of motion of liquids and in particular, water. It is branch of science that deals with the dynamics of fluids, especially incompressible fluids in motion.

The basis of computational hydrodynamic models is the set of equations that describe the motion fluids and these equations are derived from Newton's laws of motion and describe the action of force applied to the fluid; that is, the resulting changes in flow. This is the property of conservation of momentum and is simply Newton's second law: acceleration is depended upon the force exerted and proportional to its mass. 
Fig. 3 Drainage map

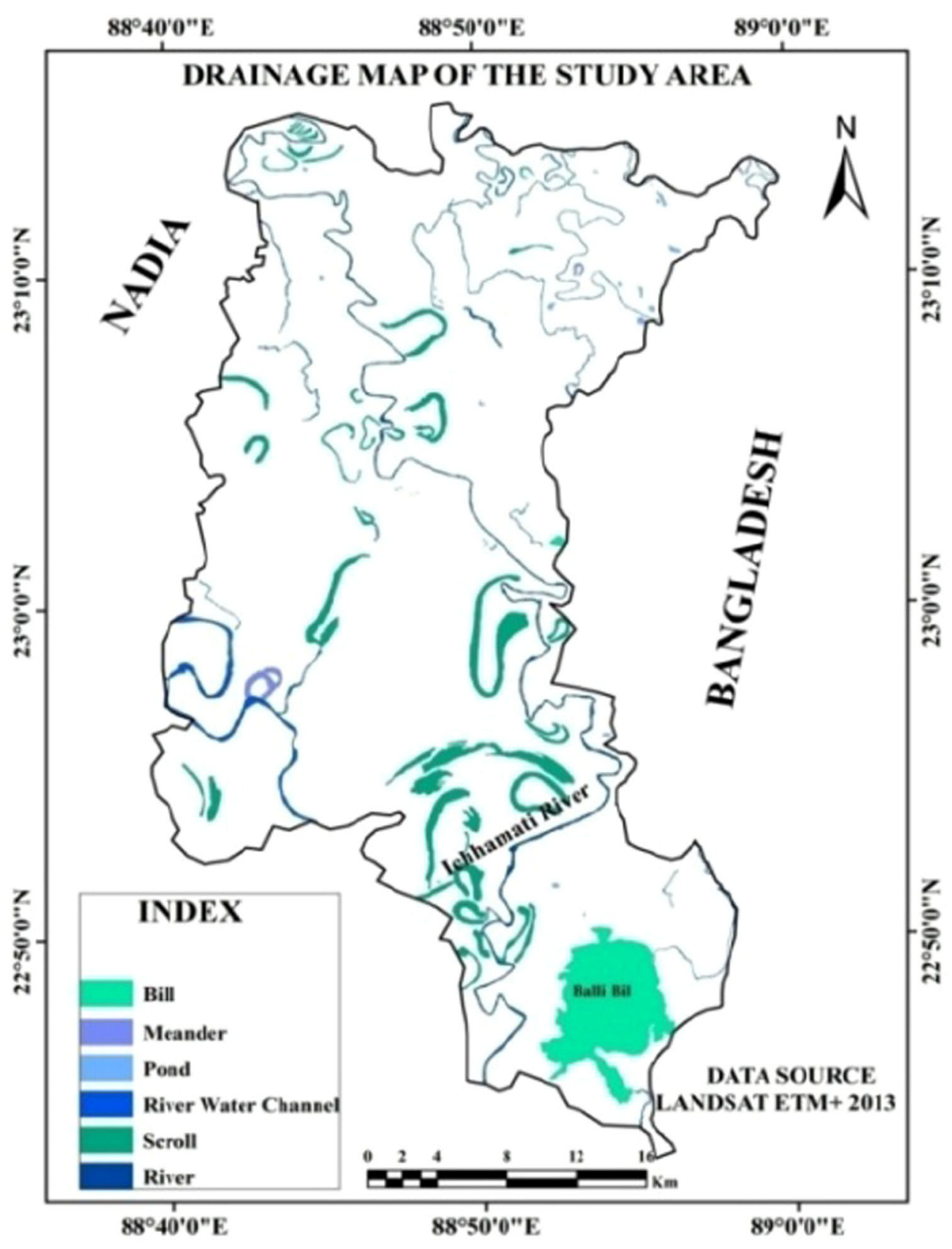

Channel hydraulics energy equation:

$Z_{2}+Y_{2}+a_{2} \frac{V_{2}^{2}}{2 g}=Z_{1+} Y_{1}+a_{1} \frac{V_{1}^{2}}{2 g}+h_{e}$

Continuity equation:

$V_{2} A_{2}=V_{1} A_{1}$

$\mathrm{Z}$ : elevation bottom of the channel, $\mathrm{Y}$ : elevation of the water surface, V: flow velocity, $\alpha$ : coefficient, g: gravity, $\mathrm{h}_{\mathrm{e}}$ : head losses, A: area of cross section.
Hydraulic analysis of Ichamati river by HEC RAC model

\section{Water surface profile}

The Ichamati river water surface profiles are computed for a variety of technical uses like tidal fluctuation and rain water during the monsoon season. Profiles are computed for flood insurance studies, flood hazard mitigation investigations, other similar design needs. The water surface profile for the 


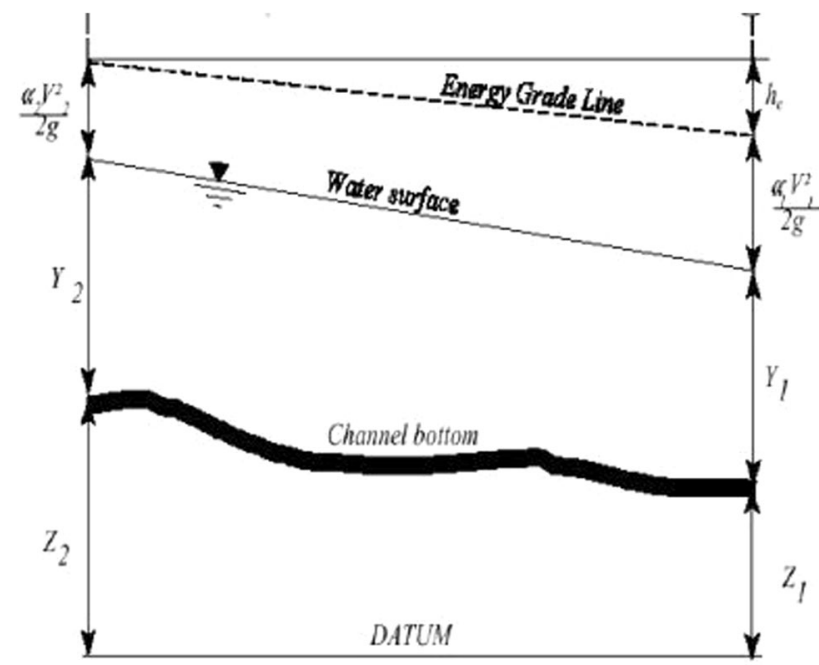

Fig. 4 Channel hydraulic

significant majority of streams can be computed using the step-profile (standard-step) method for unsteady flow. The method is based on solving the unsteady flow equations using a cross section to cross section, in these study water surface profiles for reach of Ichamati River (Fig. 4).

\section{Velocity profile of Ichamati river}

The Ichamati river mainly supercritical stream at the toe enters the jump body; it undergoes shearing action at the top as well as at the solid boundaries. The top surface of the high-velocity flow will have high relative velocities with respect to the fluid mass that overlays it. The intense shear at the surface generates a free shear layer which entrains the fluid from the overlying mass of fluid. The boundary shear at the bed causes a retardation of the velocity in a boundary layer. As a result of these actions the velocity distribution in a section at a distance 0-2000 $\mathrm{m}$ from the toe will be as shown in Fig. 5. It is seen that the velocity of Ichamati river profile has two distinct portions-a forward flow in the lower main body and a native velocity of Kalanchi region at the top. In the forward flow, the total volumetric rate of flow will be in excess of the discharge at the toe. This is due to the flow entrainment at shear layer. To maintain continuity, i.e. to account for the excess forward flow, a reverse flow exists at the top. This situation results in the formation of the roller.

\section{Cross section geometry}

Boundary geometry for the analysis of flow in natural streams is specified in terms of ground water profiles (cross Section $20 \mathrm{~km}$ reach) and the measured distances between them (reach length). Each cross section in an HEC-RAS data set is identified by a river, reach, and river station label. The cross section is described by entering the station and elevation ( $\mathrm{X}-\mathrm{Y}$ data) from left to right, with respect to looking in the downstream direction. Cross-section data are used to determine the conveyance and storage of a river channel and overbank areas (Fig. 5).
Fig. 5 General profile plotvelocities

\section{ICHAMATI RIVER}

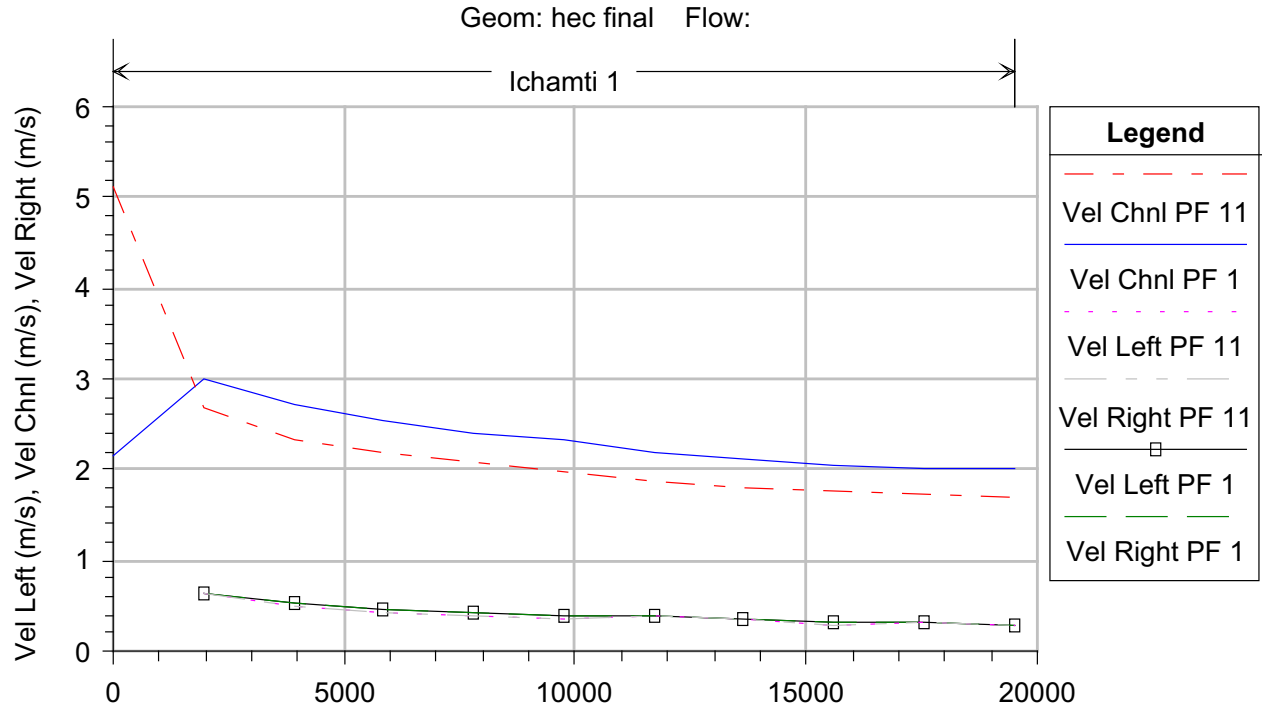

Main Channel Distance (m) 
Table 1 View hydraulic property tables of Ichamati river

\begin{tabular}{|c|c|c|c|c|c|c|c|c|c|c|}
\hline & $\begin{array}{l}\text { Elevation } \\
\text { (m) }\end{array}$ & $\begin{array}{l}\text { Area chan } \\
\left(\mathrm{m}^{2}\right)\end{array}$ & $\begin{array}{l}\text { Area } L+R \\
\left(\mathrm{~m}^{2}\right)\end{array}$ & $\begin{array}{l}\text { Area total } \\
\left(\mathrm{m}^{2}\right)\end{array}$ & $\begin{array}{l}\text { Storage area } \\
\left(\mathrm{m}^{2}\right)\end{array}$ & $\begin{array}{l}\text { Conv Ch } \\
\left(\mathrm{m}^{3} / \mathrm{s}\right)\end{array}$ & $\begin{array}{l}\text { Conv L + R } \\
\left(\mathrm{m}^{3} / \mathrm{s}\right)\end{array}$ & $\begin{array}{l}\text { Conv total } \\
\left(\mathrm{m}^{3} / \mathrm{s}\right)\end{array}$ & $\begin{array}{l}\text { Top width } \\
\text { (m) }\end{array}$ & Alpha \\
\hline 1 & 0.55 & 0.15 & 0.01 & 0.16 & 0.00 & 0.72 & 0.03 & 0.75 & 1.16 & 1.06 \\
\hline 2 & 0.66 & 0.26 & 0.04 & 0.29 & 0.00 & 1.72 & 0.11 & 1.83 & 1.28 & 1.09 \\
\hline 3 & 0.76 & 0.36 & 0.07 & 0.43 & 0.00 & 3.03 & 0.27 & 3.30 & 1.39 & 1.12 \\
\hline 4 & 0.86 & 0.46 & 0.12 & 0.58 & 0.00 & 4.62 & 0.53 & 5.16 & 1.50 & 1.15 \\
\hline 5 & 0.97 & 0.57 & 0.17 & 0.74 & 0.00 & 6.47 & 0.91 & 7.39 & 1.61 & 1.18 \\
\hline 6 & 1.07 & 0.67 & 0.24 & 0.91 & 0.00 & 8.56 & 1.43 & 9.99 & 1.72 & 1.21 \\
\hline 7 & 1.18 & 077 & 0.32 & 1.10 & 0.00 & 10.9 & 2.1 & 13.0 & 1.83 & 1.23 \\
\hline 8 & 1.28 & 0.88 & 0.41 & 1.29 & 0.00 & 13.4 & 2.9 & 16.3 & 1.94 & 1.26 \\
\hline 9 & 1.38 & 0.98 & 0.52 & 1.50 & 0.00 & 16.2 & 3.9 & 20.1 & 2.06 & 1.28 \\
\hline 10 & 1.49 & 1.09 & $0 . \mathrm{G} 3$ & 1.72 & 0.00 & 19.1 & 5.2 & 24.3 & 2.17 & 1.30 \\
\hline 11 & 1.59 & 1.19 & 0.76 & 1.95 & 0.00 & 22.2 & 6.6 & 28.8 & 2.28 & 1.31 \\
\hline 12 & 1.70 & 1.29 & 0.90 & 2.19 & 0.00 & 25.6 & 8.2 & 33.8 & 2.39 & 1.33 \\
\hline 12 & 1.80 & 1.40 & 1.05 & 2.44 & 0.00 & 29.1 & 10.1 & 39.2 & 2.50 & 1.35 \\
\hline 14 & 1.90 & 1.50 & 1.21 & 2.71 & 0.00 & 32.7 & 12.2 & 45.0 & 2.61 & 1.36 \\
\hline 15 & 2.01 & 1.60 & 1.38 & 2.99 & 0.00 & 36.6 & 14.6 & 51.2 & 2.72 & 1.38 \\
\hline 16 & 2.11 & 1.71 & 1.56 & 3.27 & 0.00 & 40.6 & 17.2 & 57.9 & 2.77 & 1.39 \\
\hline 17 & 2.22 & 1.81 & 1.75 & 3.56 & 0.00 & 44.8 & 20.1 & 64.9 & 2.82 & 1.40 \\
\hline 18 & 2.32 & 1.91 & 1.94 & 3.85 & 0.00 & 49.2 & 23.0 & 72.2 & 2.86 & 1.41 \\
\hline 19 & 2.42 & 2.02 & 2.13 & 4.15 & 0.00 & 53.7 & 26.1 & 79.8 & 2.91 & 1.43 \\
\hline 20 & 2.53 & 2.12 & 2.34 & 4.46 & 0.00 & 58.4 & 29.4 & 87.7 & 2.96 & 1.44 \\
\hline
\end{tabular}

\section{Hydrograph analysis}

Perennial streams, or streams that flow continuously throughout the year, are most likely to be fed by groundwater. These streams contain a base flow component and are candidates for a hydrograph separation method. The Ichamati River hydrograph separation method has its basis in the physical world. Figure 8 and Table 1 is a stream flow hydrograph that illustrates various rainfall pathways into a stream. Channel interception or rainfall that falls directly on the stream is represented by the blue curve (Herschy 1999). Overland flow is represented by the green curve. Subsurface flow or precipitation that infiltrates the land surface yet arrives at the stream in a short time is the major curve, and the base flow or groundwater component that enters the stream curve (Herschy 1999). All of these components add together to form the shape of the stream flow hydrograph.

\section{Discharge hydrographs of Ichamati river}

Figures 6, 7 and 8 and Tables 1,2 and 3 shows the output discharge hydrographs obtained from the various models of Ichamati River at Kalanchi and Ramnagar Point, in comparison to the measured data for this event. As the figures of the river particularly upstream of the Ramnagar to lower stream of Kalanchi river geometry approximation the tidal fluctuation. The tide speed is only slightly slower than the observed and the tide peak is comparable in magnitude to that obtained with both other models. Table 3 presents a comparison of the percent error in peak discharge calculated using

calculated peak discharge - observed peak discharge

$$
\times 100 \text { observed peak discharge }
$$

These results are quite promising when one considers that, the model both hydraulic models are uncalibrated and the channel shape has been approximated as a simple rectangle over the majority of the routing domain (i.e., with no consideration of floodplain geometry). Of particular interest are the results at two Points, downstream of the lower reach. Despite the crude geometry approximation employed for the HEC-RAS model (U.S. Corps of Engineers 2002) it still approximates the tide speed slightly better than the model.

Its over-attenuation of the flood peak magnitude can be attributed to the need to use 0 of $8 \mathrm{~m}$ to ensure solution stability.

Employing larger values would increase this effect, decreasing accuracy further. A value of 0 to $8 \mathrm{~m}$ would likely lead to solution instability (which is why the user is not allowed this option) (U.S. Corps of Engineers 2002; Taggart 1995). 
Fig. 6 General profile plothydraulic depth

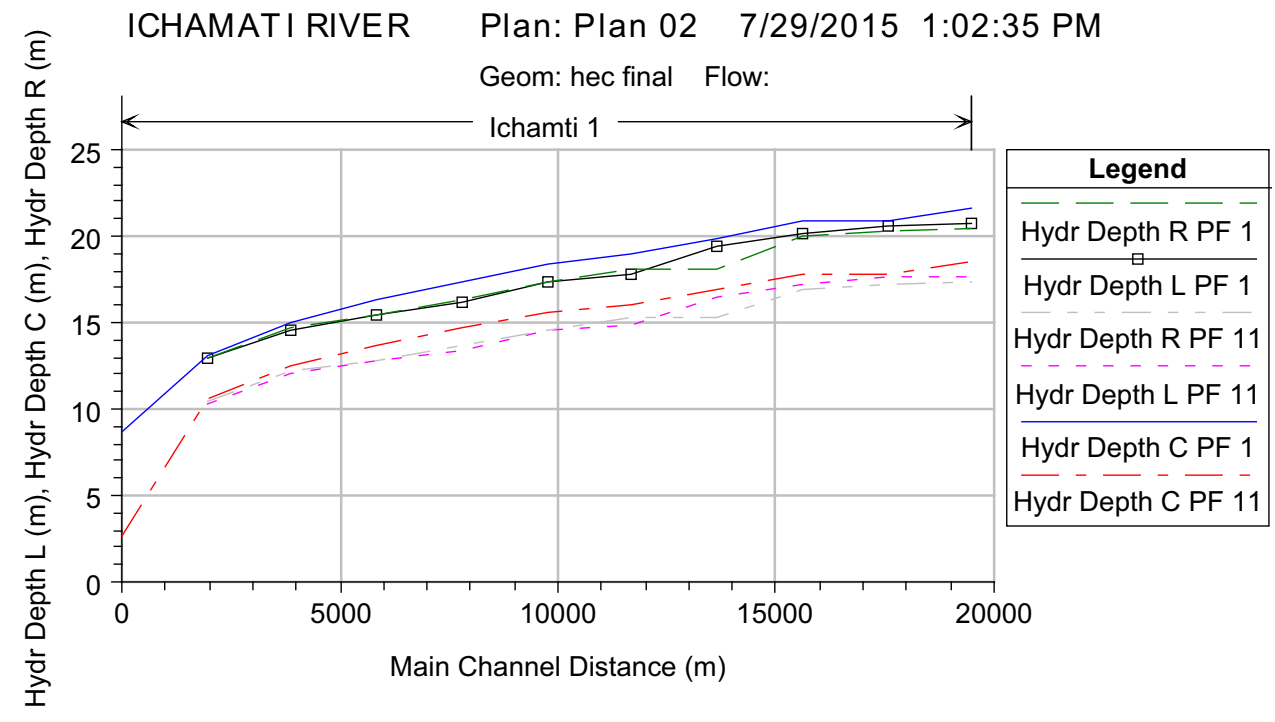

RS $=11$

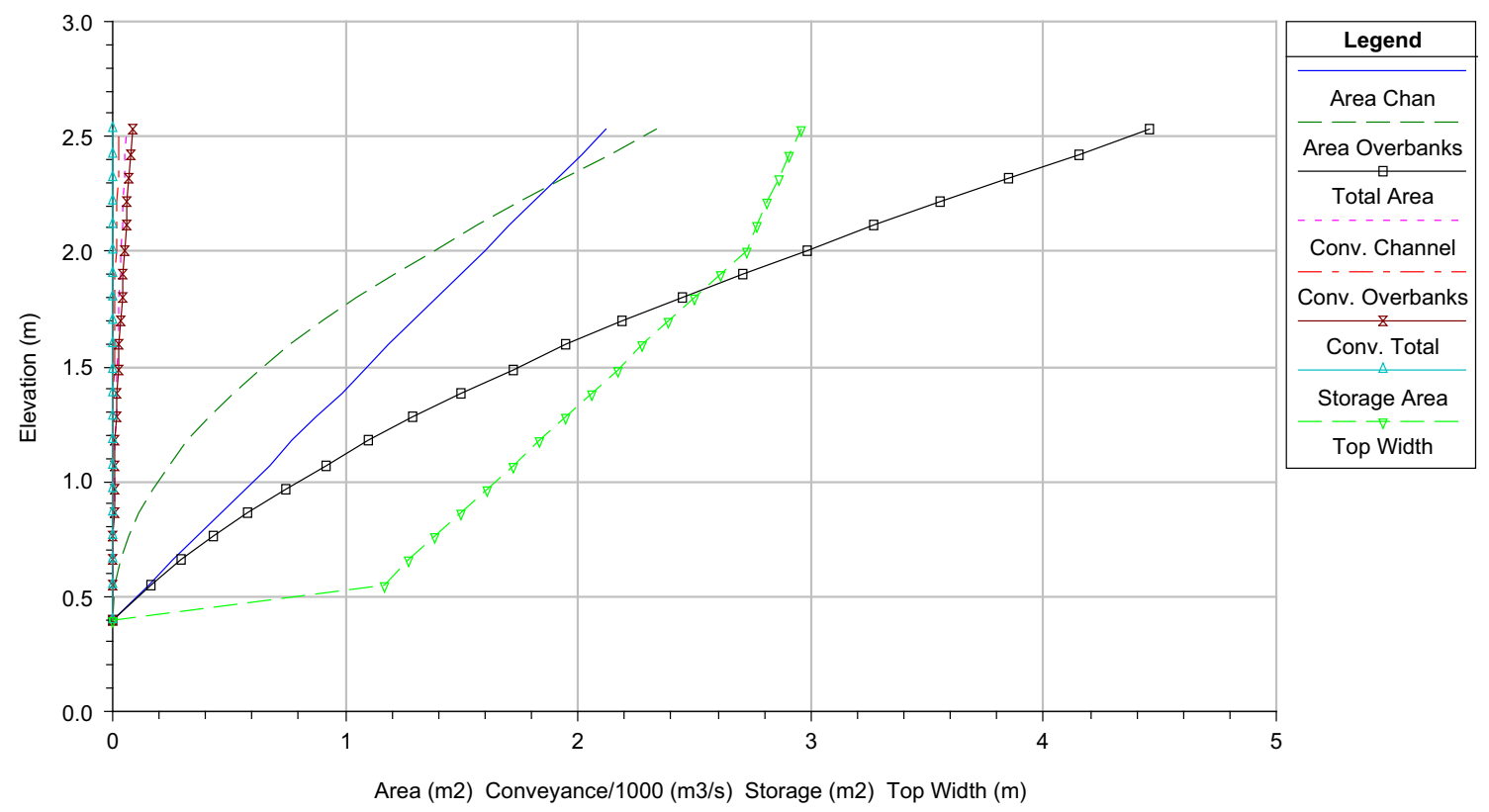

Fig. 7 Hydraulic condition of Ichamati river

\section{Bed shear stress of Ichamati river}

Provides an index of fluid force per unit area on the stream bed, which has been related to sediment mobilization and transport in many theoretical and empirical treatments of sediment transport of Ichamati river.

In the Table 3 scouring zones are determined. In this Table the column 5 shows the cross sectional flow area corresponding to respective the station. The column 1 shows the river depth below the water surface measured after incorporating the reduced level. The sectional flow in the next column is calculated using area-velocity method. The average bed slope of the channel in this $20 \mathrm{~km}$ stretch of river under study is found to be $5.06 \times 10^{-4}$. In the next two columns bed shear stress and side shear stress are calculated. We have calculated bed shear stress and side shear stress using the following formulas

Bed shear stress, $\tau_{b}=\gamma y S_{0}$, 


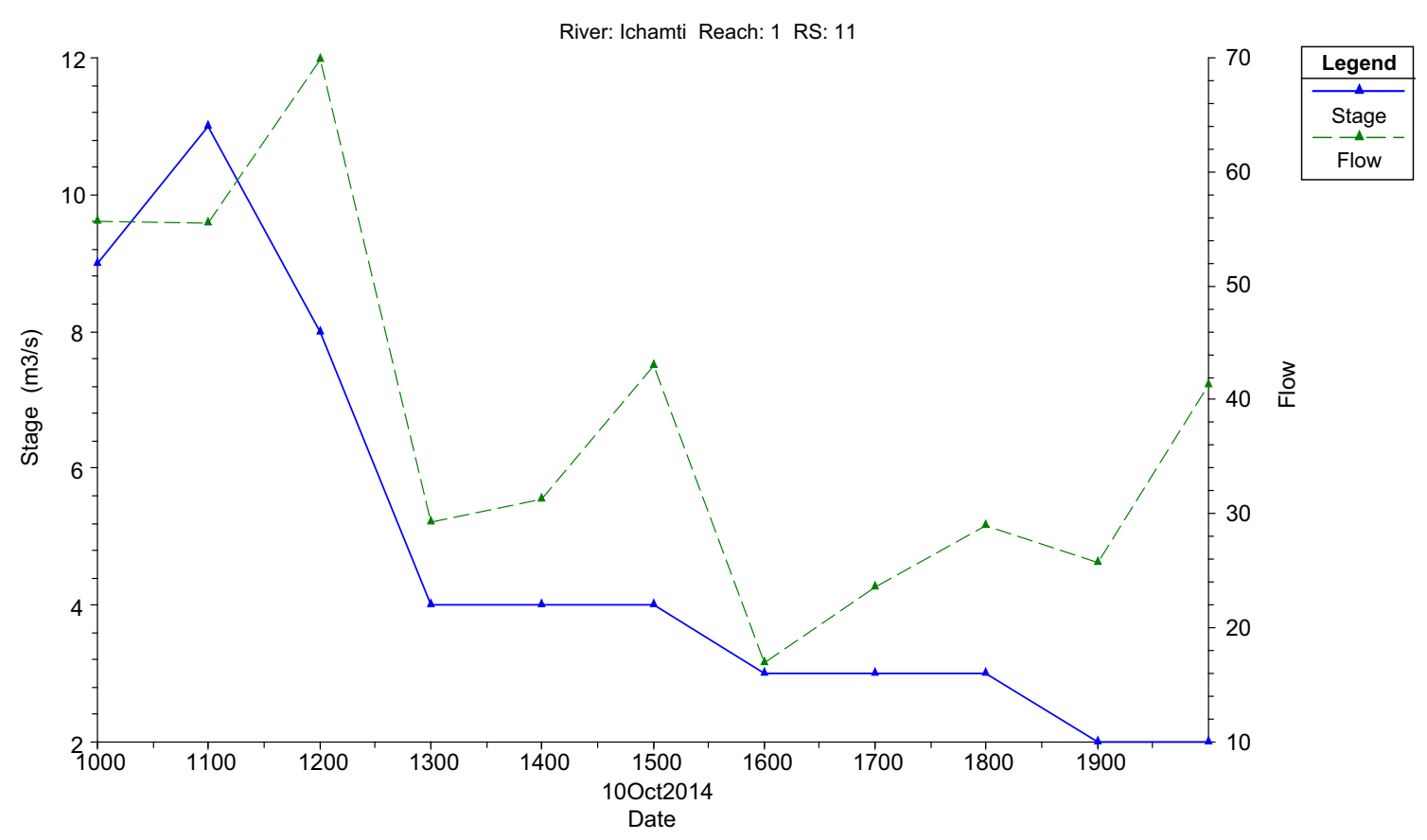

Fig. 8 Stage and flow hydrograph of Ichamati river

Table 2 Profile output tables of Ichamati river

\begin{tabular}{|c|c|c|c|c|c|c|c|c|c|c|c|c|}
\hline \multirow[b]{2}{*}{ Reach } & \multicolumn{12}{|c|}{ HEC-RAS Plan: Plan 02 River: Ichamti Reach: 1 Profile: PF 1} \\
\hline & $\begin{array}{l}\text { River } \\
\text { Sta }\end{array}$ & Profile & $\begin{array}{l}\text { Q Total } \\
\left(\mathrm{m}^{3} / \mathrm{s}\right)\end{array}$ & $\begin{array}{l}\text { Min Ch } \\
\text { El (m) }\end{array}$ & $\begin{array}{l}\text { W.S. } \\
\text { Elev (m) }\end{array}$ & $\begin{array}{l}\text { Crit } \\
\text { W.S. } \\
(\mathrm{m})\end{array}$ & $\begin{array}{l}\text { E.G. } \\
\text { Elev (m) }\end{array}$ & $\begin{array}{l}\text { E.G. Slope } \\
(\mathrm{m} / \mathrm{m})\end{array}$ & $\begin{array}{l}\text { Vel Chnl } \\
(\mathrm{m} / \mathrm{s})\end{array}$ & $\begin{array}{l}\text { Flow } \\
\text { area }\left(\mathrm{m}^{2}\right)\end{array}$ & $\begin{array}{l}\text { Top } \\
\text { width } \\
(\mathrm{m})\end{array}$ & $\begin{array}{l}\text { Froude } \\
\text { \# Chl }\end{array}$ \\
\hline 1 & 11 & PF 1 & 55.58 & 0.40 & 21.99 & & 22.15 & 0.000240 & 2.00 & 62.85 & 3.00 & 0.14 \\
\hline 1 & $10^{*}$ & PF 1 & 55.58 & 0.39 & 21.48 & & 21.64 & 0.000285 & 2.02 & 61.76 & 3.00 & 0.14 \\
\hline 1 & $9 *$ & PF 1 & 55.58 & 0.10 & 20.93 & & 21.10 & 0.000267 & 2.06 & 60.92 & 3.00 & 0.14 \\
\hline 1 & $8^{*}$ & PF 1 & 55.58 & 0.22 & 20.32 & & 20.49 & 0.000366 & 2.11 & 57.30 & 3.00 & 0.15 \\
\hline 1 & $7 *$ & PF 1 & 55.58 & 0.33 & 19.54 & & 19.72 & 0.000426 & 2.19 & 54.75 & 3.00 & 0.16 \\
\hline 1 & $6^{*}$ & PF 1 & 55.58 & 0.37 & 18.71 & & 18.92 & 0.000398 & 2.31 & 52.96 & 3.00 & 0.17 \\
\hline 1 & $5^{*}$ & PF 1 & 55.58 & 0.27 & 17.83 & & 18.05 & 0.000494 & 2.41 & 49.88 & 3.00 & 0.18 \\
\hline 1 & $4^{*}$ & PF 1 & 55.58 & 0.42 & 16.77 & & 17.02 & 0.000567 & 2.55 & 47.22 & 3.00 & 0.20 \\
\hline 1 & $3 *$ & PF 1 & 55.58 & 0.45 & 15.51 & & 15.78 & 0.000712 & 2.70 & 44.29 & 3.00 & 0.22 \\
\hline 1 & $2^{*}$ & PF 1 & 55.58 & 0.63 & 13.77 & & 14.11 & 0.001051 & 3.01 & 39.00 & 3.00 & 0.26 \\
\hline 1 & 1 & PF 1 & 55.58 & 0.14 & 9.00 & 3.64 & 9.24 & 0.011591 & 2.15 & 25.88 & 3.00 & 0.23 \\
\hline
\end{tabular}

Asterisk mentions the HEC RAS Software out for river station $1 * 2 *$ etc. multiple the average river station automatically generate, how much station you need

where $\gamma=$ specific weight of water, $9790 \mathrm{~N} / \mathrm{m}^{3}, \mathrm{y}=$ depth of water from bed, $\mathrm{m}, \mathrm{S}_{0}=$ longitudinal slope, $5.06 \times 10^{-4}$

Side shear stress, $\tau_{s}=K_{s} \tau_{b}$ where $K_{s}=0.066 m+0.67=0.066(2)+0.67=0.802$

Permissible bed shear stress on the non-cohesive bare soil has been obtained from a standard graph (referred to Table 3, Chain 2013) and its value, $\tau_{\mathrm{p}}=11 \mathrm{~N} / \mathrm{m}^{2}$.
The permissible side shear stress on the side of the channel, $\tau_{p s}=K \tau_{p}$

where $K=\sqrt{1-\frac{\operatorname{Sin}^{2} \theta}{\operatorname{Sin}^{2}}}$

$\theta=\tan ^{-1}(1 / m)=\tan ^{-1}(1 / 2)=26.56$

Assuming, angle of repose of the bare soil, $\alpha=35^{\circ}$

$K=0.63$

$\tau_{p s}=6.908 \mathrm{~N} / \mathrm{m}^{2}$ 
Table 3 Determination of scouring zone of Ichamati river. Data source: River Research Institute, Haringhata, Nadia

\begin{tabular}{|c|c|c|c|c|c|c|}
\hline River station & $\begin{array}{l}\text { Average } \\
\text { depth (m) }\end{array}$ & $\begin{array}{l}\text { Average } \\
\text { velocity }\end{array}$ & $\begin{array}{l}\text { Average } \\
\text { slope (m) }\end{array}$ & $\begin{array}{l}\text { Total discharge } \\
\left(\mathrm{m}^{3} / \mathrm{s}\right)\end{array}$ & $\begin{array}{l}\text { Sectional flow } \\
\left(\mathrm{m}^{3} / \mathrm{s}\right)\end{array}$ & $\begin{array}{l}\text { Bed shear stress } \\
\left(\mathrm{N} / \mathrm{m}^{2}\right)\end{array}$ \\
\hline Gobra & 1.57 & 0.14 & 9 & 86.32 & 55.58 & 9.81 \\
\hline Kalanchi & 2.37 & 0.22 & 11 & 82.58 & 55.5 & 8.27 \\
\hline Kalaroa road & 2.51 & 0.1 & 8 & 56.8 & 69.86 & 7.71 \\
\hline Garjala & 3.54 & 0.06 & 7 & 55.98 & 29.32 & 1.06 \\
\hline Tentulbaria & 4.07 & 0.04 & 9 & 59.66 & 31.26 & 1.29 \\
\hline Noradaha & 3.62 & 0.12 & 3 & 54.56 & 43.04 & 1.47 \\
\hline Branbaria & 3.36 & 0.18 & 3 & 93 & 40.92 & 9.18 \\
\hline Ramnagar road & 4.48 & 0.1 & 3 & 103.64 & 23.63 & 8.60 \\
\hline Ramnagar road 1 & 3.89 & 0.12 & 3 & 59.8 & 28.91 & 9.96 \\
\hline Near Angrail & 3.40 & 0.06 & 1 & 67.3 & 25.73 & 9.73 \\
\hline Angrial & 3.60 & 0.12 & 1 & 100.03 & 41.31 & 8.67 \\
\hline
\end{tabular}

From the Table 3 showing the bed shear stress and side shear stress which have crossed their corresponding permissible value.

\section{Shear stress distribution curves of Ichamati river}

- Shear stress increases with the increase of depth and width ratio from the river channel of during monsoonal season.

- Ichamati river bed condition depend on the hydraulic radius as well as velocity distribution of channel middle section of the river.

- Hydraulic radius increases with the increase of depth and width ratio.

- With increase of depth ratio, velocity increases and the correspondingly shear stress increases.

\section{In a compound meandering channel of Ichamati river}

- The bed shear stress is increasing and decreasing in the inner and outer bend respectively right bank of Ichamati river near Kalanchi and old Bongaon site.

- The maximum value of shear stress occurs along the inner bend of the main channel at low water depth ratio and maximum river are generate meandering and oxbow-lake of middle part of the river, because this upper part only depends on rain water and middle and lower part are depends on tidal fluctuation. So the middle parts of the river are manly dynamic zone, the river is disbalance of the middle part to generate oxbow and meandering.

- For higher depth ratio, the maximum shear stress occurs along the inner bend of the floodplain. Because at low over bank depths, the slow moving flow in the flood plain interact with the fast moving main channel intensely and considerable momentum exchange takes place giving rise to large non uniformity in the longitudinal velocity distribution. The maximum effected of the Ichamati river catchment area are flood plain during the monsoonal season; because this river are do not continuing suspended sediment load, the effected of maximum Block like Bagdah, Bongaon, Gaighata, Baduria, Swarupnagar and Bashirhat Block are effected by rainy season.

\section{Rating curve of Ichamati river}

In hydrology, a Rating curve is a graph of discharge versus stage for a given point on a stream, usually at gauging stations, where the stream discharge is measured across the stream channel by HEC RAS Model. Numerous measurements of stream discharge are made over a range of stream stages. The rating curve is usually plotted as discharge on $\mathrm{X}$-axis versus stage (surface elevation) on $\mathrm{y}$-axis (Fig. 9, 10, 11).

In the Figs. 5, 6, 7, and 12 are showing the results from a $20 \mathrm{~km}$ reach of Ichamati River. The computed water surface elevations are almost identical to those derived from HEC-RAS. The velocities are slightly lower because the calculation did not divide the cross section into an active flow zone and a tidal water/backwater zone. The cross sectional area occupied by moving water was therefore greater, resulting in lower velocities. This also means that HEC water surface elevation should be slightly lower which is the case. The differences in both water surface elevation and velocity near distance zero reflect different assumptions in defining computation starting values. Overall, the comparison shows that the modeling results 
Fig. 9 General profile plotsurface area
ICHAMATI RIVER Plan: Plan $02 \quad$ 7/29/2015 1:02:35 PM

Geom: hec final Flow:

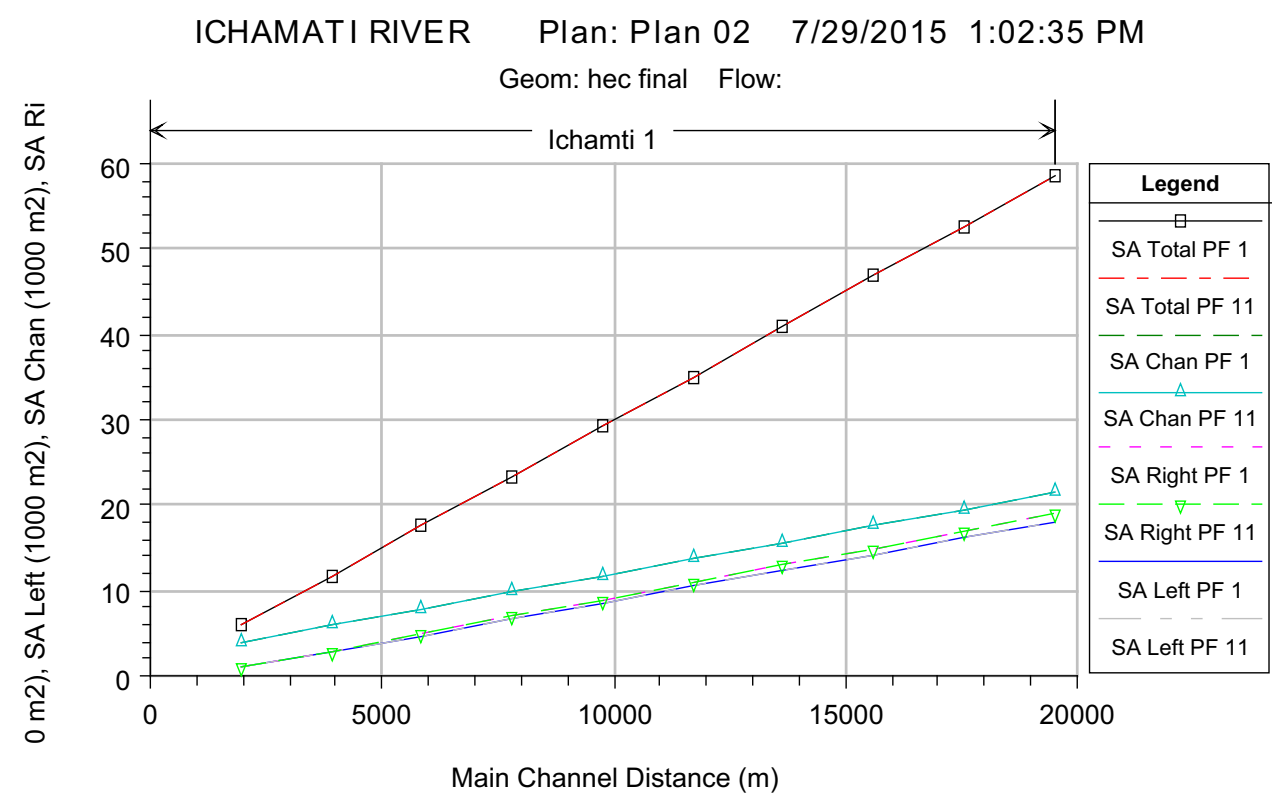

ICHAMATI RIVER Plan: Plan $02 \quad 7 / 29 / 2015$ 1:02:35 PM

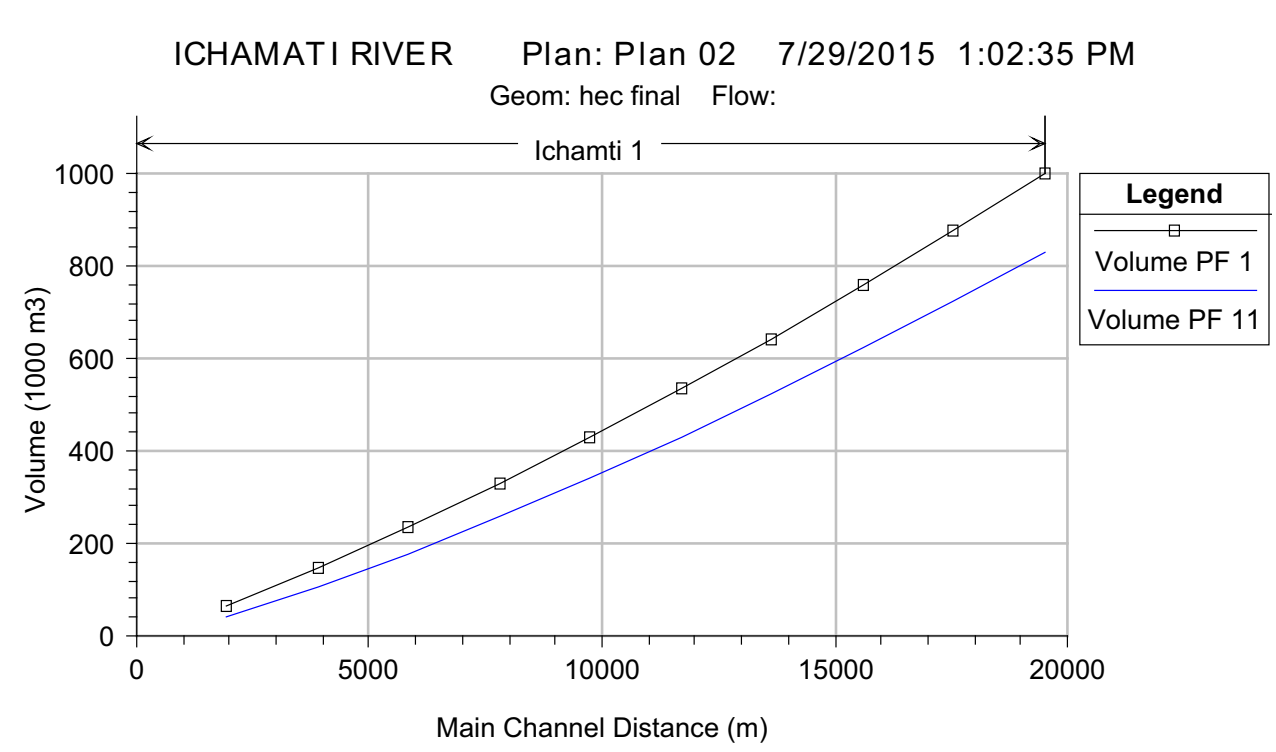

Fig. 10 General profile plottotal volume of Ichamati river are consistent with those from HEC. For the prediction result by HEC RAS model of Ichamati river is showing the Rating Curve of $20 \mathrm{~km}$ Stretch. The future prediction result shows the maximum change for two places of Kalanchi and Ramnagar in which the river will generate meander course for further adjustment with the new gradient of hydraulic discharges. In the Sundarban delta, rivers always adjust with the temporary changes of water levels, shift in turbidity maximum zones, and rapid rate of siltation by mass events (e.g. storm surges, rivers floods, subsidence etc.) and the ponding effects of drainage under present conditions. Following such adjustments the present Ichamati river section will also follow the lengthening of its course by generating meandering pattern in the near future.

\section{Conclusions}

- Flow depth, velocity, shear stress and wave celerity can be determined from flood hydraulics by the model.

- The HEC-RAS one-dimensional numerical model was essential in evaluating the long term bed change of the reach downstream of the Ichamati river.

- Understanding bed adjustments at this scope allows for proper mitigation measures at the Kalanchi and Ramnagar to predicted changes in reach scale bed degradation.

- River flow data from the one dimensional model was critical in the development of the physical model to define the modeled flow rate, and in the development of 
Fig. 11 General profile plotbed shear stress
ICHAMATI RIVER Plan: Plan $02 \quad 7 / 29 / 2015 \quad 1: 02: 35$ PM

Geom: hec final Flow:

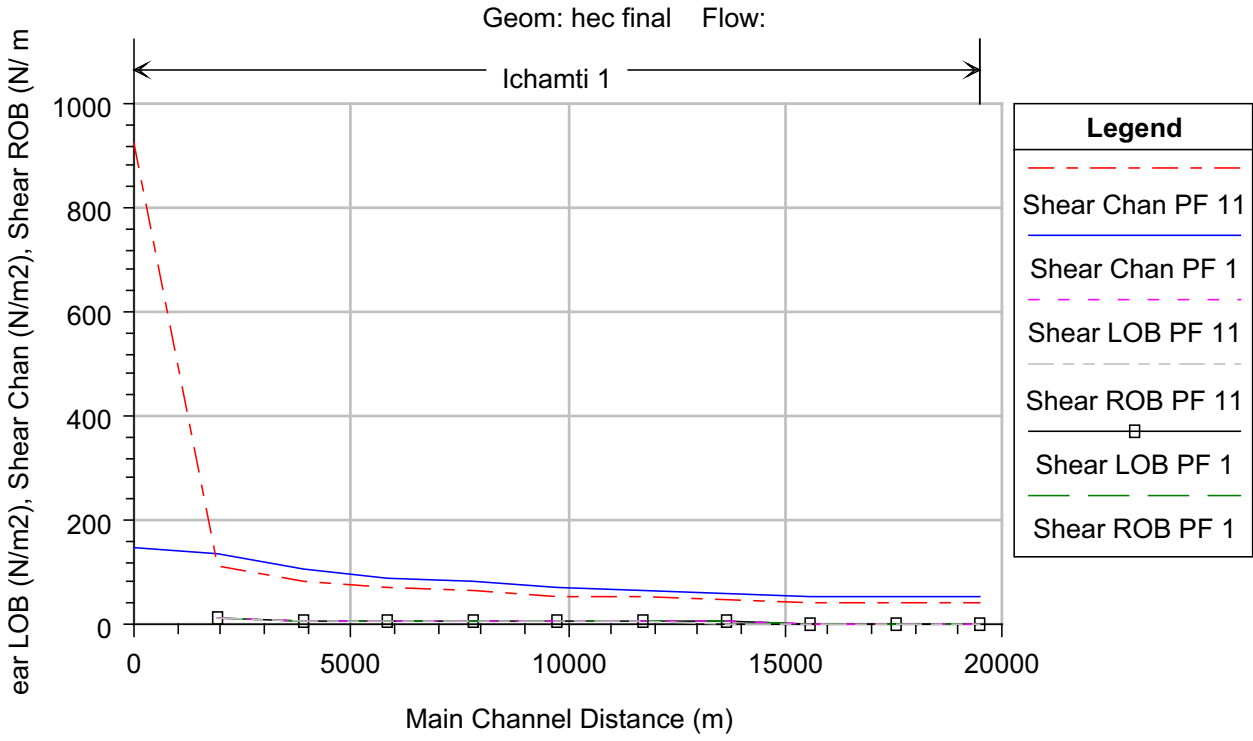

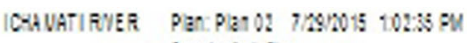

gexixted on

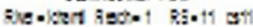

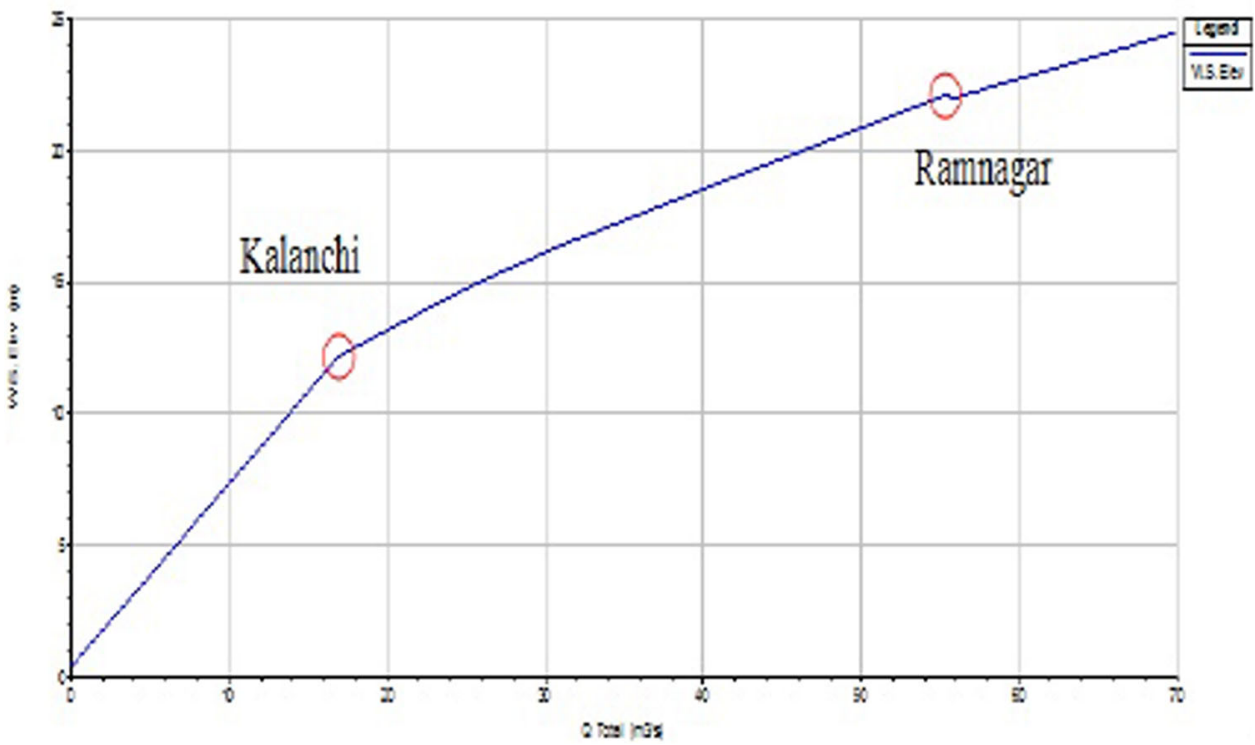

the two-dimensional numerical model to define the downstream boundary condition.

- One-dimensional models require many assumptions including the accurate representation of a river using selected cross section data, and neglecting of some orthogonal and vertical velocity components of the Ichamati river.

- For all cases shear stress increases with the increase of depth ratio and width ratio. But the increasing rate of shear stress is higher with the depth ratio in comparable to width ratio. Low magnitude of boundary shear stress is resulted in the outer bend as compare to the inner bend of a compound meandering channel.

- At low water depth ratio, the maximum value of shear stress occurs along the inner bend of the main channel. But for higher depth ratio, the maximum shear stress occurs along the inner bend of the floodplain. It is recommended that further investigation be focused on extending the present analysis to the compound meandering channel of unsymmetrical cross sections with different floodplain width. 
- The river Ichamati is adjusting its course in few sections following the temporal change of hydraulic gradient and plan shape changes by rapid siltation process through the occurrences of mass events in the Sundarban deltaic complex.

\section{References}

Acharya SK, Chakraborty P, Lahiri S, Raymahashay BC, Guha S, Bhowmik A (1999) Arsenic poisoning in the Ganges Delta. Nature 401:545

Chakravarti K (1938) Land-use in relation to the fluvial ecology in the Bhagirathi-Jalangi riparian tract-Calcutta University, M.A. thesis, (unpublished)

Chain DA (2013) Water-resources engineering, 3rd edn. Prentice Hall, Cloth, pp 960 (ISBN-13: 978-0132833219, ISBN-10: 0132833212)

Herschy RW (ed.) (1999) Hydrometry-Principles and Practices. Wiley, Chicheste, pp VI + 376. ISBN 0-471-97350-5

Mondal I, Bandyopadhyay J (2014a) Coastal zone mapping through geospatial technology for resource management of Indian Sundarban, West Bengal, India. Int J Remote Sens Appl 4(2):103-112

Mondal I, Bandyopadhyay J (2014b) Environmental change of trans international boundary Indo-Bangladesh border of Sundarban
Ichamati river catchment area using geoinformatics techniques, West Bengal, India. Univ J Environ Res Tech 4(3):143-154

Mondal I, Bandyopadhyay J (2014c) Morphodynamic change of the Ichamati river and land use/land cover changes through space and time using remote sensing and GIS techniques North 24 Parganas, West Bengal, India, (Bagdah, Bongaon, Gaighata And Swarupnagar Block, Hyderabad, India, December 9-12, 2014

Mondal M, Satpati LN (2012) Morphodynamic setting and nature of bank erosion of the Ichamati River in Swarupnagar and Baduria Blocks, 24 Parganas (N), West Bengal, Indian. J Spatial Sci 3.0(2) Winter, Issue 2012, pp 35-43

Niyogi D (1975) Quaternary geology of the coastal plain in West Bengal. Indian J Earth Sci 2:51-61

Roy AD (1952) Safety first and the holding of assets. Econometrica 20:431-449

Sengupta S (1966) Geological and geophysical studies in western part of Bengal Basin, India. Bull Am Assoc Petrol Geol 50:1001-1017

Taggart J (1995) The peace river natural flow and regulated flow scenarios-daily flow data report. Surface Water Assessment Branch, Alberta Environmental Protection, Edmonton, AB

Umitsu M (1993) Late quaternary sedimentary environments and landforms in the Ganga Delta. Sediment Geol 83:177-186

U.S. Corps of Engineers (2002) HEC-RAS River Analysis System, Hydraulic Reference Manual. Hydraulic Engineering Center Report CPD-69, Davis, CA 